\title{
Spiroplasma citri Spiralin Acts In Vitro as a Lectin Binding to Glycoproteins from Its Insect Vector Circulifer haematoceps
}

\author{
Nabil Killiny, Michel Castroviejo, and Colette Saillard
}

First and third authors: UMR 1090, INRA et Université Victor Segalen Bordeaux 2, BP 81, 33883 Villenave d'Ornon Cedex, France; and second author: UMR-5097, CNRS, Université Victor Segalen Bordeaux 2, 33076, Bordeaux Cedex.

Accepted for publication 11 January 2005.

\begin{abstract}
Killiny, N., Castroviejo, M., and Saillard, C. 2005. Spiroplasma citri spiralin acts in vitro as a lectin binding to glycoproteins from its insect vector Circulifer haematoceps. Phytopathology 95:541-548.

In order to understand the molecular mechanisms underlying transmission of Spiroplasma citri by the leafhopper Circulifer haematoceps, we screened leafhopper proteins as putative $S$. citri-binding molecules using a spiroplasma overlay assay of protein blots (Far-western assay). Insect proteins were separated by one- or two-dimensional sodium dodecyl sulfate polyacrylamide gel electrophoresis, blotted, and probed with S. citri proteins. In this in vitro assay, we found that spiroplasma proteins exhibited affinity for seven leafhopper proteins. The interactions between $S$. citri proteins and insect proteins with molecular masses of 50 and $60 \mathrm{kDa}$ were found to be sugar sensitive. These insect proteins were
\end{abstract}

ABSTRACT

The plant-pathogenic mollicute Spiroplasma citri inhabits the phloem sieve tubes of infected plants. It is transmitted naturally in a propagative manner from plant to plant by sap-feeding leafhopper vectors: two Circulifer spp. $(18,36)$ and three Scaphytopius spp. (23,35,37). $S$. citri has been cultured since 1970 from sweet orange trees affected with stubborn disease (43). It infects many plant species other than citrus, including Madagascar periwinkle (Catharanthus roseus), in which it induces stunting, leaf yellow, and wilting (9).

The circulative route of $S$. citri through an experimental leafhopper vector, Euscelis plebejus (33), and a natural vector, Circulifer tenellus (29), is well established. In order to be transmitted to plants, two physical barriers within the leafhopper, the gut and salivary glands walls, must be crossed by $S$. citri. During insect feeding on infected plants, spiroplasmas move from the food canal through the foregut and accumulate in the midgut and hindgut. Then, they move across the basal lamina, circulate in the hemocoel where they multiply, enter the salivary glands, and are released in the salivary canal. Once they are present in the salivary canal, they can flow with salivary secretions through the saliva duct into the host plant during feeding.

Electron microscopic observations of $S$. citri in membranebound cytoplasmic vesicles at the basal plasmalemma of gut epithelial cells suggest that $S$. citri invades the gut and also the salivary glands of its vector $C$. tenellus by endocytosis $(15,25)$. Recent findings concerning the movement of $S$. kunkellii through

Corresponding author: C. Saillard; E-mail address: saillard@bordeaux.inra.fr

DOI: 10.1094/PHYTO-95-0541

(C) 2005 The American Phytopathological Society identified as high mannose $\mathrm{N}$-glycoproteins, which support an interaction of glycoprotein-lectin type with $S$. citri proteins. Lectin detection in $S$. citri has revealed only one protein of $24 \mathrm{kDa}$. Using a leafhopper protein overlay assay on an $S$. citri protein blot, one spiroplasma protein with a similar molecular mass of $24 \mathrm{kDa}$ was shown to display an insect protein-binding capacity. This protein was identified as the spiralin, which is the most abundant membrane protein of $S$. citri. Far-western experiments performed with purified spiralin and insect glycoproteins confirmed the binding of spiralin to the insect glycoproteins of 50 and $60 \mathrm{kDa}$. Thus, the spiralin could play a key role in the transmission of $S$. citri by mediating spiroplasma adherence to epithelial cells of insect vector gut or salivary gland.

Additional keywords: S. citri transmission. the gut epithelial cell layer of its insect vector Dalbulus maidis are in agreement with this process (38). Earlier studies reporting that spiroplasmas traverse the epithelial cell layer of gut between cells in a process called diacytosis $(1,28)$ were not confirmed by these results.

In the case of human and animal mycoplasmas, successful colonization of the host cells required adhesion as the first step. This event is mediated by mycoplasma surface proteins and, among these proteins, adhesins play an important role in invasion and pathogenicity $(4,41)$.

Little is known about the biology of recognition and invasion of insect gut and salivary glands by $S$. citri. The passage of $S$. citri through both physical barriers probably is mediated by receptorligand interactions (25), although no receptors on the surface of insect's organs were identified. However, in S. citri, one adhesionrelated protein, P89, was found to be directly involved in the spiroplasma-insect cell interaction (56).

During the last two decades, much attention has been focused on the possibility that cellular recognition is mediated by carbohydrates and lectins. Because the basal lamina of insect organs is highly glycosylated $(2,14)$, it is reasonable to postulate that carbohydrate moieties might be likely targets for $S$. citri interaction.

To further investigate the nature of the spiroplasma-insect cell interaction and to characterize the nature of the specific molecules involved in this interaction, we developed a protein-blotting protein-overlay assay (Far-western). Our results suggest that $S$. citri undergoes a specific interaction with $C$. haematoceps glycoproteins during insect invasion. Various experimental approaches were used to identify $S$. citri proteins that bind to insect carbohydrates. One $S$. citri protein, the spiralin, identified as a lectin, binds to two insect glycoproteins with apparent masses of 50 and $60 \mathrm{kDa}$. 


\section{MATERIALS AND METHODS}

Preparation of $S$. citri proteins for sodium dodecyl sulfatepolyacrylamide gel electrophoresis and protein overlay assay. $S$. citri GII3, originally isolated from its leafhopper vector C. haematoceps captured in Morocco (51), was cultivated in SP4 medium (48) at $32^{\circ} \mathrm{C}$. S. citri cells from exponential growth phase were harvested by centrifugation at $20,000 \times g$ for $20 \mathrm{~min}$ at $4^{\circ} \mathrm{C}$ and washed three times in washing buffer (HEPES, $8 \mathrm{mM}$; sucrose, $280 \mathrm{mM}$; $\mathrm{pH}$ 7.4). Protein concentration was determined by the Bradford procedure (8) using the a protein assay kit (BioRad Laboratories, Hercules, CA) with ovalbumin as standard.

For overlay assays, cells from a $50-\mathrm{ml}$ culture were resuspended in $200 \mu \mathrm{l}$ of phosphate-buffered saline (PBS), $\mathrm{pH} 7.4$ ( $2 \mathrm{mM} \mathrm{KH}_{2} \mathrm{PO}_{4}, 8 \mathrm{mM} \mathrm{Na} \mathrm{HPO}_{4}, 0.14 \mathrm{M} \mathrm{NaCl}, 2 \mathrm{mM} \mathrm{KCl}$ ) containing EDTA-free protease inhibitors cocktail (one tablet per $10 \mathrm{ml}$ ) (Roche, Meylan Cedex, France). Then, cells were lysed by submitting them to five rounds of freezing at $-20^{\circ} \mathrm{C}$ and thawing on ice. Protein concentrations were usually near $5 \mathrm{mg} / \mathrm{ml}$. Aliquots of the suspension were frozen at $-20^{\circ} \mathrm{C}$ until used.

Membrane proteins of $S$. citri were extracted with Triton X-114 according to a previously described method (7).

$S$. citri polyclonal and monoclonal antibodies. Polyclonal serum was from a rabbit that had been immunized with $S$. citri strain GII-3. Immunoglobulins were purified as described before (44). Hybridomas producing monoclonal antibodies were obtained as described by Foissac et al. (17). Monoclonal antibody 12G9 reacted with the spiralins of different $S$. citri strains (17), including strain GII-3 (unpublished data).

Sodium dodecyl sulfate polyacrylamide gel electrophoresis and blotting. S. citri membrane proteins in sample buffer (26) were loaded $(50 \mu \mathrm{g} / \mathrm{well})$ on a $12.5 \%$ polyacrylamide gel and submitted to electrophoresis as previously described (34). After electrophoresis, proteins were transferred to nitrocellulose membrane for $60 \mathrm{~min}$ at $10 \mathrm{~V}$ (47) using a semi-dry transfer apparatus (Bio$\mathrm{Rad})$. For renaturation of proteins and blocking the unoccupied spaces, membrane was incubated overnight at $4^{\circ} \mathrm{C}$ in $\mathrm{PBS}, \mathrm{pH}$ 7.4, containing 6\% nonfat dry milk (Sigma-Aldrich, St. Louis). After blocking, membrane was used immediately for Western or negative Far-western

A healthy colony of $C$. haematoceps was reared in an insectproof cage at $30^{\circ} \mathrm{C}$ on stock plants as described previously (16). Adult leafhoppers were ground in a potter-Elvehjem-grinder (VWR International, Fontenay-sous-Bois Cedex, France) with sample buffer (26) (40 insects per $500 \mu \mathrm{l}$ ). Then the mixture was boiled for $15 \mathrm{~min}$ and centrifuged for $1 \mathrm{~min}$ at $200 \times g$. Proteins were not further purified to avoid inadvertently removing proteins of interest. Aliquots of supernatant $(25 \mu \mathrm{l})$ were subjected to sodium dodecyl sulfate-polyacrylamide gel electrophoresis (SDSPAGE) (12.5\%), and proteins were visualized by staining with Coomassie brilliant blue. For a preparative SDS-PAGE (12.5\%), the suspension $(500 \mu \mathrm{l})$ was applied to a $14-\mathrm{cm}$-wide slot under denaturing conditions as described by Laemmli (26). After electrophoresis, proteins were transferred to nitrocellulose membranes as above. The saturated membranes were used immediately for overlay assay with $S$. citri proteins.

Leafhopper two-dimensional PAGE. Forty $C$. haematoceps adults were ground in liquid nitrogen and the powder was dispersed in ice-cold acetone containing $10 \%$ trichloroacetic acid (TCA) and $0.07 \% \beta$-mercaptoethanol. After $1 \mathrm{~h}$ at $-20^{\circ} \mathrm{C}$, the suspension was centrifuged at $14.000 \times g$ for $10 \mathrm{~min}$ and the pellet was washed two times in the same solution without TCA. After the last centrifugation, the pellet was resuspended in $20 \mu \mathrm{l}$ of rehydration buffer (Bio-Rad). Approximately $1 \mathrm{mg}$ of protein was obtained.

Immobilized pH gradient strips (IPGs), pH 3 to 10 (Bio-Rad), $17 \mathrm{~cm}$ long, were incubated for $13 \mathrm{~h}$ in rehydration buffer $(300 \mu \mathrm{l})$ containing $200 \mu \mathrm{g}$ of insect proteins. Isoelectric focusing (IEF) was carried out using a Protean IEF cell (Bio-Rad). After IEF, the IPGs were incubated in two equilibration buffers for $10 \mathrm{~min}$ each according to the manufacturer's instructions.

The proteins in the equilibrated IPGs were separated on $12.5 \%$ SDS-PAGE using a Protean II xi cell. Electrophoresis was carried out at $50 \mathrm{~V}$ at room temperature until the dye front ran off the gel. Proteins were visualized by Coomassie brilliant blue or transferred onto nitrocellulose membrane and membrane was blocked as described above. After blocking, membrane was used immediately for Far-western experiments.

Far-western experiments. The Far-western protocol was used as described $(21,49)$ with some modifications. After blocking, blots of total insect proteins or insect glycoproteins separated by SDS-PAGE were cut into 7-mm strips. Each strip was incubated with shaking (60 oscillations/min) overnight at $4{ }^{\circ} \mathrm{C}$ in $2 \mathrm{ml}$ of PBS buffer with $0.1 \%$ of Tween 20 (PBS-Tween) containing $10 \mu \mathrm{g}$ of whole cell lysate of $S$. citri proteins. A blot with proteins separated by two-dimensional (2D) electrophoresis was incubated in the same conditions, in $20 \mathrm{ml}$ of PBS-Tween containing $100 \mu \mathrm{g}$ of $S$. citri proteins. Control experiments were conducted omitting spiroplasma proteins. After three 15-min washings in PBS-Tween, blots were incubated for $1 \mathrm{~h}$ at room temperature in PBS buffer with purified polyclonal immunoglobulin Gs (IgGs) against total $S$. citri proteins at a final concentration of $5 \mu \mathrm{g} / \mathrm{ml}$. After three washings, blots were incubated at room temperature for $1 \mathrm{~h}$ with peroxidase-conjugated goat anti-rabbit IgGs (Sigma-Aldrich). Blots were rinsed three times in PBS-Tween and antigen-antibody complexes were detected with SuperSignal West Pico chemiluminescent substrate according to the manufacturer (Pierce, Rockford, IL). Then, blots were exposed for $\approx 10$ min onto X-ray film.

For sugar competition experiments, proteins of $S$. citri in PBS solution with different amounts $(0.1,0.5$, or $1 \mathrm{M})$ of $\mathrm{D}(+)$ mannose, methyl- $\alpha$-mannopyranoside, or $\mathrm{D}(+)$ glucose were added to insect protein blots.

Identification of $S$. citri proteins involved in interaction with insect proteins. Negative Far-western experiments were carried out to identify the proteins of $S$. citri implicated in the interaction with insect proteins. Insect protein overlay assays were conducted in a manner similar to that described above for the $S$. citri protein overlay assay.

Blots of spiroplasma membrane proteins, after blocking, were incubated with shaking, overnight at $4^{\circ} \mathrm{C}$ with a clarified insect suspension (two insects per milliliter of PBS) at $2 \mathrm{ml} / \mathrm{strip}$. Immunodetection of $S$. citri proteins was performed with polyclonal IgGs $(5 \mu \mathrm{g} / \mathrm{ml})$ or monoclonal antibodies $(5 \mu \mathrm{g} / \mathrm{ml})$ against spiralin in the same conditions described above for the Farwestern. The proteins of $S$. citri implicated in the interaction with insect proteins were masked and not recognized by antibodies. Detection of the antibody-antigen complexes were performed as above. Sugar competition experiments were carried out with $2 \mathrm{ml}$ of PBS containing proteins from five insects and methyl- $\alpha$ mannopyranoside $(0.1,0.2,0.5$, or $1 \mathrm{M})$. Control blots with no insect protein overlay were directly incubated in $S$. citri polyclonal IgGs or monoclonal antibodies against the spiralin.

Glycoproteins detection. Saturated blots of $S$. citri and insect proteins were incubated overnight in PBS containing peroxidaselabeled Concanavalin A at $50 \mu \mathrm{g} / \mathrm{ml}$. After washing three times in PBS-0.05\% Tween 20, the interaction was visualized with SuperSignal West Pico chemiluminescent substrate as above.

Purification of insect glycoproteins by lectin affinity chromatography. The HiTrap Lectin Test Kit (Amersham Biosciences Europe, Orsay Cedex, France), consisting of four glycoprotein binding columns (HiTrap concanavalin A [Con A], HiTrap Lens culinaris (lentil) agglutinin [LCA], HiTrap wheat germ agglutinin [WGA], HiTrap peanut agglutinin [PNA]), was used for purification of insect glycoproteins. The lectins used, their abbreviations, their major sugar specificities, and the elution buffers are listed in Table 1. 
Four hundred healthy $C$. haematoceps adults were ground in liquid nitrogen and the powder was resuspended in $1 \mathrm{ml}$ of solubilization buffer (SB) (2\% Chaps in PBS, pH 7.0). The insoluble materials were removed by centrifugation at $4,000 \times g$ at room temperature for $2 \mathrm{~min}$. Aliquots of the supernatant $(200 \mu \mathrm{l})$ were diluted with $800 \mu$ l of binding buffer specific for the lectin column used, as recommended by the manufacturer. Total volume $(1 \mathrm{ml})$ was directly loaded on lectin columns for glycoproteins purification.

After elution with recommended elution buffers, glycoproteins were precipitated in ice-cold acetone, centrifuged at $20,000 \times g$ for $30 \mathrm{~min}$ at $4^{\circ} \mathrm{C}$, air dried, and resuspended in PBS buffer. Protein concentrations were estimated by the Bradford method. Purified glycoproteins were separated on SDS-PAGE $(10 \mu \mathrm{g} / \mathrm{well})$ and silver stained. For electroblotting onto nitrocellulose membrane, the amount of glycoproteins was $50 \mu \mathrm{g} /$ well. Before use in Farwestern experiments, the membrane was blocked as above.

Lectins detection in $\boldsymbol{S}$. citri. Blots of $S$. citri proteins blocked with $6 \%$ dry milk, as above, were incubated for $2 \mathrm{~h}$ at room temperature in $2 \mathrm{ml}$ of PBS containing different amounts of ovalbumin $(5,10$, and $15 \mu \mathrm{g})$. The control was made by omitting ovalbumin. After washing, blots were incubated with peroxidaselabeled Con A $(50 \mu \mathrm{g} / \mathrm{ml})$ in PBS buffer for $1 \mathrm{~h}$. Then, the blots were rinsed in PBS-Tween and detection of the lectin-glycoprotein complex was performed with SuperSignal West Pico chemiluminescent substrate as described above.

Spiralin purification. A pellet from 1 liter of $S$. citri culture was washed and resuspended in $5 \mathrm{ml}$ of Hepes-sucrose buffer. Spiroplasma cells were disrupted by sonication (rate: $50 \%$ pulses/s, 50 watts, $0^{\circ} \mathrm{C}, 1 \mathrm{~min}$ of sonication and $2 \mathrm{~min}$ on ice alternatively, five times) (Vibracell Sonicator; Sonics \& Materials, Inc., Danbury, CT). The mixture was clarified by centrifugation at $20,000 \times g$ for $30 \mathrm{~min}$ at $4^{\circ} \mathrm{C}$. The pellet was suspended in $5 \mathrm{ml}$ of $0.1 \mathrm{M}$ citrate buffer, $\mathrm{pH} 5.6$, with $10 \mathrm{mM}$ of phenylmethylsulfonyl fluoride (PMSF). The suspension first was fractionated on an anionic column (Mono S HR 5/5; Amersham Biosciences). The sample composed of the proteins which were not absorbed on the anionic column $(\mathrm{pI}>5.6)$ was diluted with phosphate buffer, $\mathrm{pH}$ 7.5 , and subjected to separation on a cationic column (Mono Q HR 5/5) because of the spiralin pI, which is 8.3. Proteins absorbed on the column $(\mathrm{pI}>7.5)$ were eluted with a $20-\mathrm{ml} \mathrm{NaCl}$ linear gradient from 0 to $1 \mathrm{M}$ in phosphate buffer $(\mathrm{pH} 7.5)$. The eluted proteins were monitored by absorbance at $280 \mathrm{~nm}$ and some fractions were analyzed on SDS-PAGE. Western blot analyses were performed on selected fractions containing a protein of $24 \mathrm{kDa}$, using monoclonal antibodies against spiralin.

\section{RESULTS}

Affinity of $S$. citri proteins for leafhopper proteins. Insect proteins separated by SDS-PAGE in one dimension were stained with Coomassie brilliant blue (Fig. 1A) or blotted onto nitrocellulose and probed with $S$. citri proteins $(5,10$, or $15 \mu \mathrm{g})$. Seven significant bindings were revealed by polyclonal IgGs against total $S$. citri proteins (Fig. 1B, lanes 2, 3, and 4). In a control experiment in which $S$. citri proteins were omitted from the overlay assay, no reactions with polyclonal IgGs were found (Fig. 1B, lane 1). To ascertain the binding of spiroplasma proteins to one immobilized leafhopper protein, the gel overlay assay was carried out on protein blots issued from 2D-SDS-PAGE (Fig. 2A). Spiroplasma proteins were found to bind to a set of insect proteins having apparent molecular masses of $60,50,35,30,25,18$, and $16 \mathrm{kDa}$ (Fig. 2B). In order to determinate whether the binding of $S$. citri proteins to insect proteins occurred in a lectin-mediated manner, Far-western experiments were performed in the presence of increasing amounts of $\mathrm{D}(+)$ mannose, methyl- $\alpha$-mannopyranoside, and $\mathrm{D}(+)$ glucose as competitors (Fig. 3A to $\mathrm{C}$ ). In all six replications of this assay, the presence of sugars interfered in the binding of $S$. citri proteins with insect proteins. A difference in the intensity of the signals was observed near insect proteins of 35 , $30,25,18$, and $16 \mathrm{kDa}$. Furthermore, in the presence of $0.1 \mathrm{M}$ of different sugars (Fig. 3A to C, lane 1), faint signals (reduced bindings) were detected near insect proteins of 50 and $60 \mathrm{kDa}$. With increasing amounts of sugar $(0.5$ and $1 \mathrm{M})$, these bindings were completely inhibited (Fig. 3A to C, lanes 2 and 3). These sugarsensitive bindings suggested that the interactions between $S$. citri and insect proteins of 50 and $60 \mathrm{kDa}$ were lectin-glycoprotein.

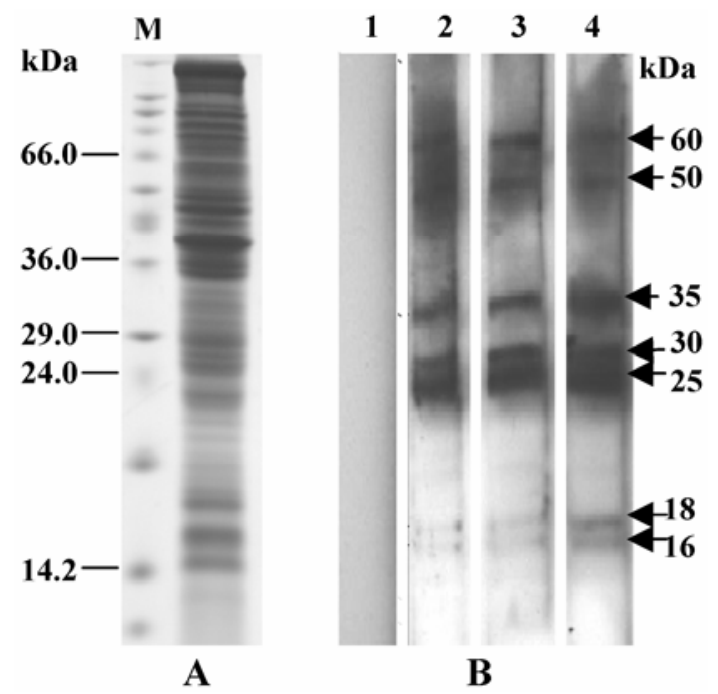

Fig. 1. Far-western experiment: binding of Spiroplasm citri proteins to Circulifer haematoceps proteins separated by sodium dodecyl sulfate-polyacrylamide gel electrophoresis (SDS-PAGE). A, Whole-body proteins of one leafhopper were analyzed by SDS-PAGE (12.5\%), stained with Coomassie brilliant blue. B, Proteins of 40 insects $(800 \mu \mathrm{g})$ were separated on a preparative polyacrylamide gel and electrophoretically transferred onto nitrocellulose membrane. Saturated membrane was cut into 20 strips (width, $7 \mathrm{~mm}$ ). The strips were probed with different amounts of whole $S$. citri cell lysate proteins (lane 1, $0 \mu \mathrm{g}$; lane 2, $5 \mu \mathrm{g}$; lane 3, $10 \mu \mathrm{g}$; lane 4, $15 \mu \mathrm{g}$ ). Anti-S. citri polyclonal immunoglobulin Gs (IgGs) were used to detect bound spiroplasma proteins. Peroxidase-conjugated goat anti-rabbit IgGs were used as secondary antibodies and detection was performed with chemiluminescent substrate. Arrows on the right indicate the seven significant bindings between proteins of $S$. citi and insect proteins having apparent molecular masses of 60, 50, 35, 30, 25,18 , and $16 \mathrm{kDa} . \mathrm{M}=$ molecular mass marker; relative molecular masses are indicated on the left.

TABLE 1. Lectins used in the affinity chromatography for the purification of glycoproteins: specificity and elution buffers

\begin{tabular}{|c|c|c|}
\hline Lectins & Specificity & Elution buffer \\
\hline Concanavalin A (Con A) & $\begin{array}{l}\text { Branched mannose, carbohydrates with terminal mannose or } \\
\text { glucose }(\alpha \mathrm{Man}>\alpha \mathrm{Glc}>\mathrm{GlcNAc})\end{array}$ & $\begin{array}{l}1 \mathrm{M} \text { methyl- } \alpha \text {-mannopyranoside, } 20 \mathrm{mM} \text { Tris-HCl, } 0.5 \mathrm{M} \\
\mathrm{NaCl} \text {, pH } 7.4\end{array}$ \\
\hline Lens culinaris agglutinin (LCA) & $\begin{array}{l}\text { Branched mannose with fucose linked } \alpha(1,6) \text { to the } N \text {-acetyl- } \\
\text { glucosamine, }(\alpha \mathrm{Man}>\alpha \mathrm{Glc}>\mathrm{GlcNAc})\end{array}$ & $\begin{array}{l}1 \mathrm{M} \text { methyl- } \alpha \text {-mannopyranoside, } 20 \mathrm{mM} \text { Tris- } \mathrm{HCl}, 0.5 \mathrm{M} \\
\mathrm{NaCl}, \mathrm{pH} 7.4\end{array}$ \\
\hline Wheat germ agglutinin (WGA) & $\begin{array}{l}\text { Core of N-linked oligosaccharides, [GlcNAc }(\beta 1,4 \mathrm{GlcNAc})> \\
\beta \text { GlcNAc] }\end{array}$ & $\begin{array}{l}0.5 \mathrm{M} N \text {-acetylglucosamine, } 20 \mathrm{mM} \text { Tris- } \mathrm{HCl}, 0.5 \mathrm{M} \mathrm{NaCl} \text {, } \\
\text { pH } 7.4\end{array}$ \\
\hline Peanut agglutinin (PNA) & Terminal $\beta$-galactose, $(\mathrm{Gal} \beta 1,3 \mathrm{GalNAc}>\alpha$ and $\beta \mathrm{Gal})$ & $\begin{array}{l}1 \mathrm{M} \text { D-galactose, } 10 \mathrm{mM} \text { sodium phosphate, } 0.15 \mathrm{M} \mathrm{NaCl} \text {, } \\
0.5 \mathrm{mM} \mathrm{MgCl}_{2}, 0.5 \mathrm{mM} \mathrm{CaCl}_{2}, \mathrm{pH} 7.4\end{array}$ \\
\hline
\end{tabular}


Detection and purification of glycoproteins. The classical methods used for detection of glycoproteins directly in gels, such as selective carbohydrate silver staining, periodic acid Schiff staining, and lectin (Con A) blotting, have not allowed the detection of glycoproteins in S. citri. Glycoproteins were detected by these classical methods only in insects (data not shown).

Purification of insect glycoproteins were performed on four lectin columns. With WGA, Con A, and LCA columns, glycoproteins were in the elution fractions. With the PNA column, no glycoproteins were obtained in the elution buffer. Using the same columns, glycoproteins also were not obtained from $S$. citri. These results are consistent with those obtained with the classical methods.

Affinity of $\boldsymbol{S}$. citri proteins for insect glycoproteins. To determine whether spiroplasma proteins display affinity for insect glycoproteins, Far-western assays were performed using whole $S$. citri cell lysate proteins as the overlay $(10 \mu \mathrm{g})$. With insect glycoproteins purified from WGA, Con A, and LCA columns (Fig. 4A to $\mathrm{C}$, lane 1), two signals were obtained only for glycoproteins of 50 and $60 \mathrm{kDa}$ (Fig. 4A to C, lane 2). These interactions between spiroplasma proteins and insect glycoproteins explain the lack of binding observed with sugars in the same molecular mass region (Fig. 3A to C).

Negative Far-western and competition with methyl- $\alpha$ mannopyranoside. To identify the proteins of $S$. citri involved in the interaction with the insect proteins, Far-western experiments were carried out on spiroplasma membrane protein blots with insect proteins as the overlay. Membrane proteins of $S$. citri involved in bindings were masked and not detected by $S$. citri antibodies. Antibodies against whole $S$. citri cells recognized many proteins among the membrane proteins of $S$. citri (Fig. 5A, lane 1). Previous results have shown that the protein which is the major antigen recognized by the polyclonal antibodies is the $24-\mathrm{kDa}$ spiralin (55). The comparison between the pattern obtained in the protein overlay assay revealed by the polyclonal IgGs (Fig. 5A, lane 2) and Western blot (Fig. 5A, lane 1) showed that one or several proteins near $24 \mathrm{kDa}$ were masked by insect proteins and were not detected by the antibodies. These masked proteins appeared when insect proteins with increasing amounts of methyl- $\alpha$-mannopyranoside sugar were used as the overlay (Fig. 5A, lanes 3, 4, 5, and 6). Similar experiments performed with the monoclonal antibodies against spiralin demonstrated that one of these proteins that bound to insect proteins was spiralin (Fig. 5B, lanes 3, 4, 5, and 6). The sugar-sensitive interaction observed between spiralin and insect proteins suggested that the spiralin might be a lectin.

Lectin detection in $\boldsymbol{S}$. citri. A blot of $S$. citri proteins was incubated in PBS buffer, pH 7.4, containing ovalbumin as a glycoprotein, followed by binding to peroxidase-labelled Con A. With increasing amount of ovalbumin, one protein of $24 \mathrm{kDa}$ appeared as the only lectin in the $S$. citri proteins pattern (Fig. 6, lanes 2, 3, and 4 ). No protein was detected when experiment was carried out without ovalbumin (Fig. 6, lane 1).

Affinity between spiralin and insect glycoproteins. Aliquots of eluted fractions from the cationic column were analyzed on SDS-PAGE (Fig. 7A, lanes 2, 3, 4, 5, and 6) and one aliquot was

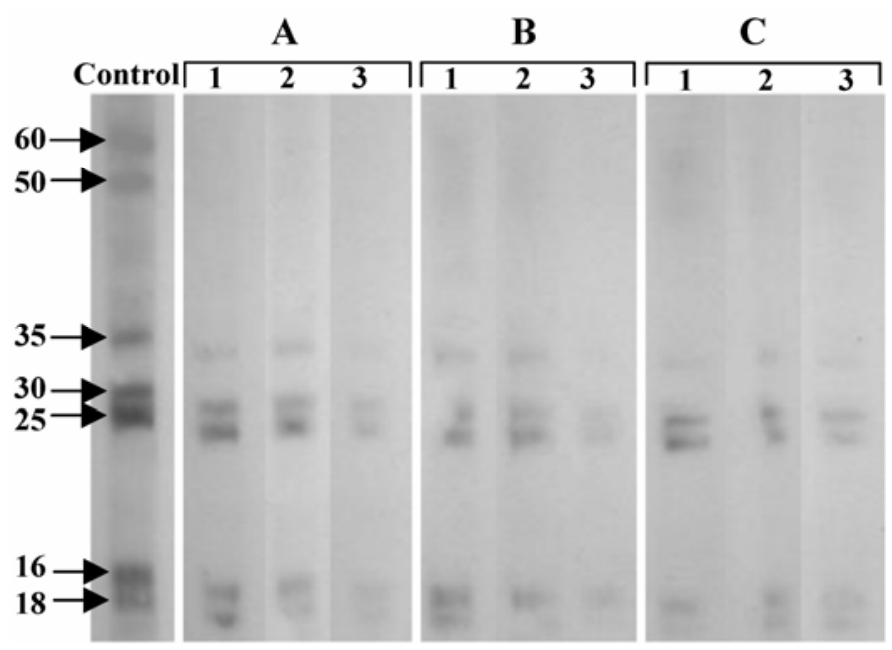

Fig. 3. Sugar inhibition of binding between Spiroplasm citri proteins and insect proteins. Forty insect proteins were separated on a preparative polyacrylamide gel (12.5\%) and electrophoretically transferred onto nitrocellulose membrane. Saturated membrane was cut into 7-mm strips. A control strip was incubated overnight with $10 \mu \mathrm{g}$ of whole $S$. citri cell lysate proteins. Other strips were incubated with the same amount of $S$. citri proteins in the presence of $\mathbf{A}$, D+ mannose, $\mathbf{B}$, methyl $\alpha$ mannopyranoside, and $\mathbf{C}$, D+ glucose as follows: lane 1, 0.1 M; lane 2, 0.5 M; lane 3, $1 \mathrm{M}$. Bindings between $S$. citri proteins and insect proteins were detected as in Figure 1. The molecular mass standards $(\mathrm{kDa})$ are indicated on the left.
A

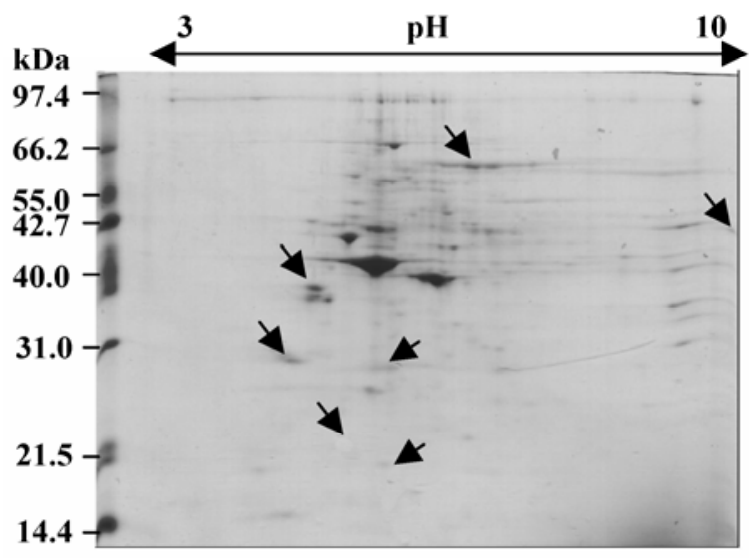

B

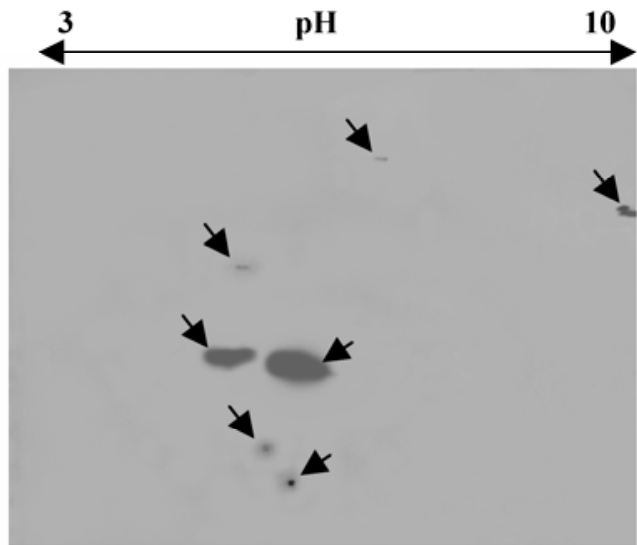

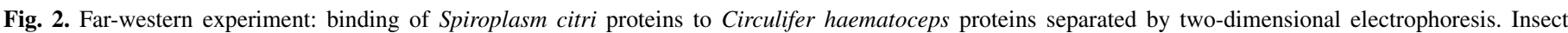

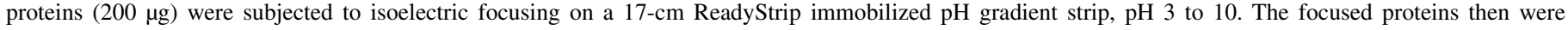

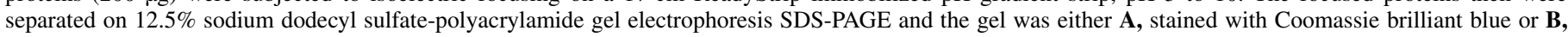

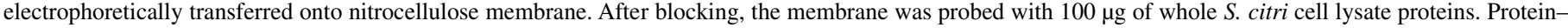

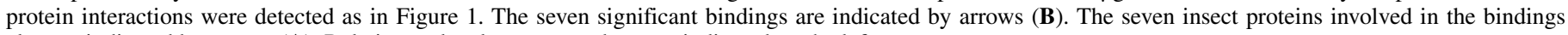
also are indicated by arrows (A). Relative molecular mass markers are indicated on the left. 
analyzed in a Western blot with monoclonal antibodies against spiralin. A single band was observed in lane 6 (Fig. 7A) corresponding to a protein of $24 \mathrm{kDa}$. This protein was identified as spiralin by monoclonal antibodies (Fig. 7B, lane 2). Blots of purified insect glycoproteins (Fig. 7C, lane 1) were overlaid with $10 \mu \mathrm{g}$ of $S$. citri whole-cell proteins (lane 2) or with $1 \mu \mathrm{g}$ of spiralin (lane 3 ) and probed with monoclonal antibodies against spiralin. Significant bindings between the two insect glycoproteins of 50 and $60 \mathrm{kDa}$ and the purified spiralin were observed (Fig. 7C, lane 3). Same bindings were also observed in lane 2. The spiralin did not bind any glycoproteins from insect vector except those of 50 and $60 \mathrm{kDa}$.

\section{DISCUSSION}

As a prelude to understanding the molecular mechanisms underlying $S$. citri transmission, we have used a protein overlay assay (Far-western) to investigate binding of spiroplasma to proteins of its vector $C$. haematoceps. Far-western assays commonly are used in plant virus research to investigate the relationship of the viruses with their vectors $(5,45,50)$. Similar assays were used to study human and animal mycoplasma interactions with host eukaryotic cells $(24,27,57,58)$. Glycolipid host receptors for Mycoplasma hyopneumoniae have been identified (58) by using a thin-layer chromatography overlay assay.

In our work, using a Far-western assay, $S$. citri proteins bound to seven insect proteins. Because of the sugar-dependent nature of the observed interactions, suggesting lectin-glycoprotein bindings, we have looked for glycoproteins and lectins in both partners.

The nondetection of glycoproteins in total S. citri proteins was in good agreement with previous reports, in which the authors failed to detect glycoproteins on $S$. citri protein blots after staining of polyacrylamide gel with periodic acid Schiff reagent $(22,55)$. However, binding of some lectins to $S$. citri cell surfaces was observed before (22) and a protein that specifically binds Con A was isolated from the membrane of $S$. citri (46). Unfortunately, the preparation was only partially pure, being contaminated by a small amount of another protein of the membrane and also

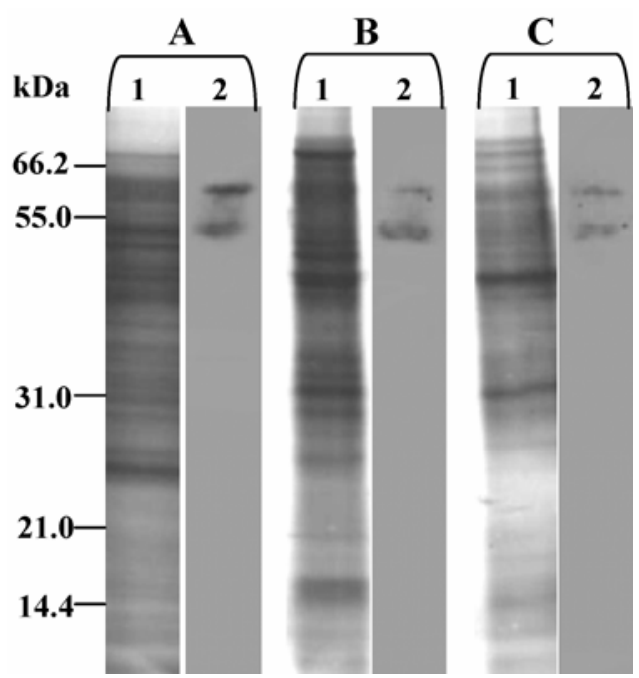

Fig. 4. Binding experiments between purified insect glycoproteins and whole Spiroplasm citri cell lysate proteins. Glycoproteins purified from A, wheat germ agglutinin, $\mathbf{B}$, concanavalin $\mathrm{A}$, and $\mathbf{C}$, Lens culinaris agglutinin columns were separated by sodium dodecyl sulfate-polyacrylamide gel electrophoresis and silver stained (strip 1: $10 \mu \mathrm{g} /$ well) or electrotransferred (strip 2: $50 \mu \mathrm{g} / \mathrm{well}$ ). After blocking, all strips were incubated with $10 \mu \mathrm{g}$ of whole $S$. citri cell lysate proteins. Bindings between $S$. citri proteins and insect glycoproteins were detected as in Figure 1. Relative molecular mass markers are indicated on the left. by an exogenous polypeptide tentatively identified as a Concanavalin A subunit (53).

With the different techniques used in this study, glycoproteins were detected only in the insect. With the PNA lectin column, which has an affinity for $N$-acetyl galactosamine, the common core structure of $O$-glycans, we did not detect any glycoproteins

A

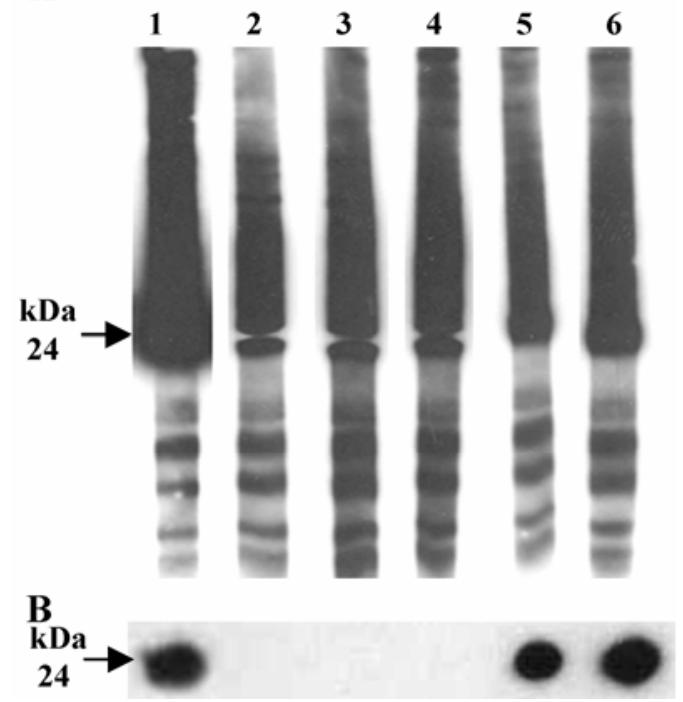

Fig. 5. Negative Far-western experiments: binding of insect proteins to Spiroplasm citri membrane proteins separated by sodium dodecyl sulfate-polyacrylamide gel electrophoresis (SDS-PAGE). S. citri membrane proteins (Triton X-114 insoluble fraction) were loaded on SDS-PAGE (50 $\mu \mathrm{g} / \mathrm{well})$ and blotted onto nitrocellulose. Western blot analysis was carried out with A, polyclonal immunoglobulin Gs (IgGs) against $S$. citri proteins strip 1) or B, monoclonal antibodies against spiralin (strip 1) followed by immunological detection as in Figure 1. Other strips were incubated with insect proteins $(40 \mu \mathrm{g})$ in the presence of increasing amounts of methyl- $\alpha$-mannopyranoside (strip 2, no sugar; strip 3, 0.1 M; strip 4, 0.2 M; strip 5, 0.5 M; strip 6, $1 \mathrm{M}$ ). A, Polyclonal IgGs and B, monoclonal antibodies were used as the primary antibodies. Immunodetection procedure was performed as described in Figure 1. Arrows on the left of A1 and B1 indicate the molecular mass of spiralin. Note that spiroplasma proteins bound to insect proteins were masked and not recognized by polyclonal IgGs (A, strips 2,3 , and 4 ) or monoclonal antibodies (B, strips 2, 3, and 4).

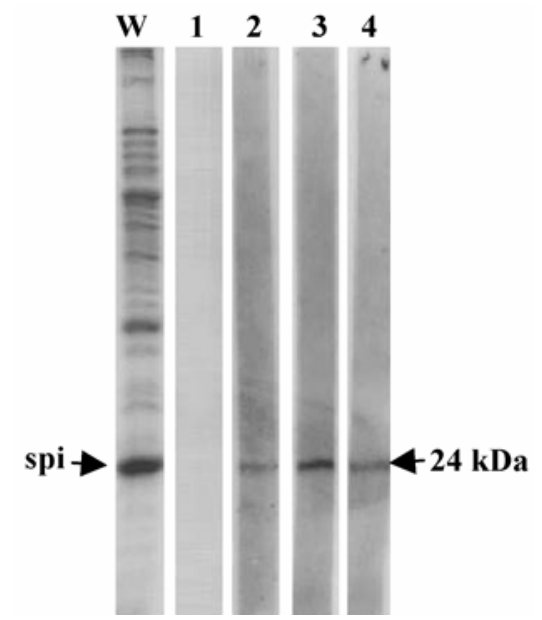

Fig. 6. Lectin detection in Spiroplasm citri. Blots of S. citri proteins were incubated with increasing amounts of ovalbumin as a glycoprotein (blot $1,0 \mu \mathrm{g}$; blot 2, $5 \mu \mathrm{g}$; blot $3,10 \mu \mathrm{g}$; blot $4,15 \mu \mathrm{g}$ ) and probed with peroxydase-labeled concanavalin A $(50 \mu \mathrm{g} / \mathrm{ml})$. Detection of peroxydase was performed with chemiluminescent substrate. Arrow on the right side indicates the lectin detected. Arrow on left side of the S. citri proteins blot (W) probed with polyclonal immunoglobulin Gs indicates spiralin (spi). 
in $C$. haematoceps, probably due to the low amount of $O$-glycans in the insect. This is consistent with previous studies which have shown that insect cells have a reduced capability for $O$-glycosylation of foreign polypeptides $(2,19,30)$. Numerous glycoproteins were purified from WGA, LCA, and Con A columns, suggesting that the glycoproteins of the whole insect are predominantly $\mathrm{N}$ glycans with some possible $O$-glycans. From each purified glycoprotein suspension, only two glycoproteins of 50 and $60 \mathrm{kDa}$ bound to $S$. citri proteins. According to the specificity of WGA, LCA, and Con A, these insect glycoproteins were $N$-glycoproteins that displayed a high content of mannose with fucose-linked $\alpha$ $(1,6)$ to $N$-acetylglucosamine.

These results indicate that bindings could arise if surface lectins expressed by the bacteria were able to interact with sugar groups on the insect glycoproteins, which could be receptors for spiroplasmas. It is well known that various forms of carbohydrates covering the eukaryotic cell surface are used by microbial pathogens as attachment sites. Host cell surface sialoglycoproteins and glycolipids have been reported to be receptors for the attachment of human and animal mycoplasmas $(31,39,40,58)$. Studies on the adherence of $S$. citri to a monolayer of $C$. tenellus-cultured cells have demonstrated that carbohydrates have no effect on spiroplasma-insect attachment, suggesting that glycoconjugates are not involved in the $S$. citri adherence to insect cells (56). In our study, competition with carbohydrates reduced the binding of spiroplasma proteins to insect glycoproteins of 50 and $60 \mathrm{kDa}$. It is important to note that the concentration of sugar used $(1 \mathrm{M})$ is higher than that used by Yu et al. (56). For clover phyllody phytoplasma, a gene encoding a putative $O$-sialoglycoprotein endopeptidase was found. As reported by the authors, this enzyme may act on host cell glycoproteins to enhance the attachment of the phytoplasma to insect vector gut tissues (12).

In our analysis, among purified insect glycoproteins, sialoglycoproteins could be present, because WGA lectin selectively binds terminal $\mathrm{N}$-acethylglucosamine and sialic acid residues (54). The ability of hemipteran insect cells to produce sialylated$\mathrm{N}$-glycans was not investigated. However, it is known that, in some insects, such as members of Lepidoptera, cells contain small amounts of sialic acid and sialylation of glycoproteins is a highly specialized function that probably occurs rarely $(20,32)$. If the glycosylation pathways in leafhopper cells are similar to those of Lepidoptera spp., these findings strongly suggest that $S$. citri receptors in insect are $\mathrm{N}$-glycosylated proteins with some possible sialoglycoproteins.

Negative Far-western experiments showed that a $24-\mathrm{kDa}$ protein of $S$. citri binds to insect glycoproteins. Competition with increasing amounts of sugar allowed detection of this protein as a lectin. Using monoclonal antibodies against spiralin, we demonstrated that this protein is the spiralin. Because the search for lectin among all $S$. citri proteins revealed only one lectin of $\approx 24 \mathrm{kDa}$, we postulate that this unique lectin and the spiralin are the same protein. In addition, two insect glycoproteins of 50 and $60 \mathrm{kDa}$ displayed strong affinity to purified spiralin. Spiralin is one of the most thoroughly characterized $S$. citri membrane proteins $(6,11,17)$. A model in which spiralin could form a protein carpet covering the entire spiroplasma surface was proposed (10) and its requirement for efficient transmission of $S$. citri by its leafhopper was described (13).

Recently, ultrastructural studies on phytopathogenic spiroplasmas indicated that helical spiroplasma cells possess a tip structure at the end of the helices (3). Various proteins on the tip structure may participate in the spiroplasma orientation and adherence to insect cell surface proteins, as is the case for adhesion proteins found on the tip structure of $M$. pneumoniae (42). Spiralin covering the entire surface of the spiroplasma (10) could not play a role in vivo in the adherence mediated via the terminal tip structure. It could be involved in the interaction between the pleïomorphic forms of spiroplasma and the membranous vesicles within the cytoplasm of the leafhopper midgut or salivary glands epithelial cells observed by Wayadande et al. (52).

When taken together, the results of the current study suggest that, in vitro, the interaction of $S$. citri with two leafhopper glycoproteins with apparent masses of 50 and $60 \mathrm{kDa}$ is mediated in a lectin manner. The most likely $S$. citri candidate for this molecular interaction is the spiralin. These findings were based on our binding studies that might have excluded certain interactions present in vivo which are dependant on environmental aspects.

A

B

C

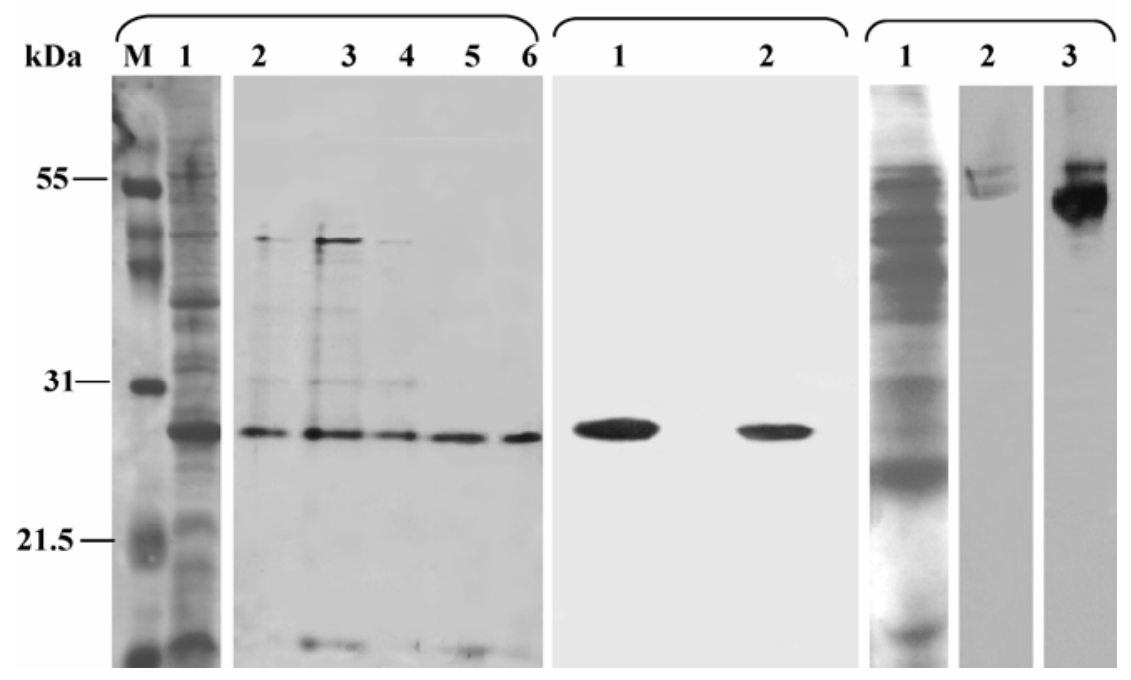

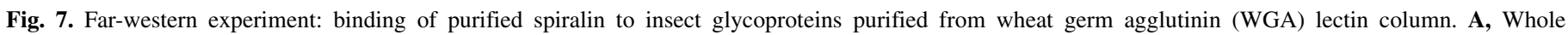

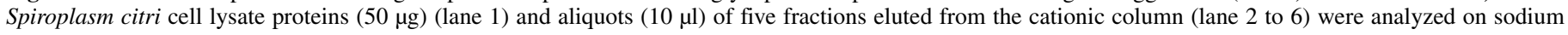

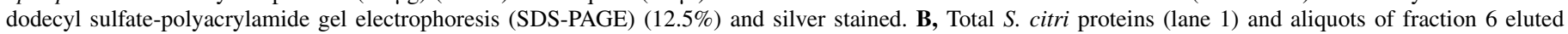

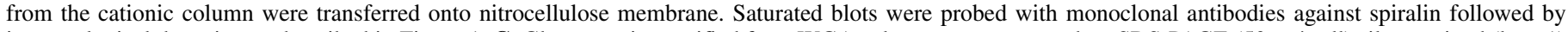

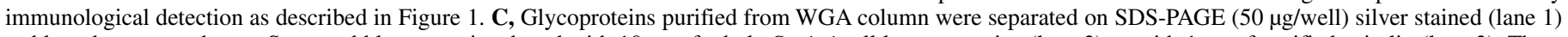

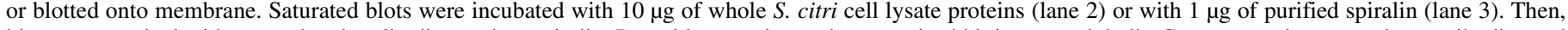

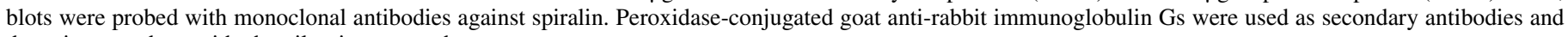
detection was done with chemiluminescent substrate. 


\section{ACKNOWLEDGMENTS}

Support for N. Killiny was provided by the Egyptian Ministry of Higher Education. We thank X. Foissac, INRA-BORDEAUX, for helpful discussions on the insect and protein interactions.

\section{LITERATURE CITED}

1. Alivizatos, A. S., and Markham, P. G. 1986. Acquisition and transmission of corn stunt spiroplasma by Its leafhopper vector Dalbulus maidis. Ann. Appl. Biol. 108:535-544.

2. Altmann, F. 1996. N-glycosylation in insects revisited. Trends Glycosci. Glycotechnol. 8:101-114.

3. Ammar, el-D., Fulton, D., Bai, X., Meulia, T., and Hogenhout, S. A. 2004. An attachment tip and pili-like structure in insect- and plant-pathogenic spiroplasmas of the class Mollicutes. Arch. Microbiol. 181:97-105.

4. Balish, M. F., and Krause, D. C. 2002. Cytadherence and the cytoskeleton. Pages 491-518 in: Molecular Biology and Pathogenicity of Mycoplasmas. S. Razin and R. Herrman, eds. Kluwer Academic/Plenum Publishers, New York.

5. Bandla, M. D., Campbell, L. R., Ullman, D. E., and Sherwood, J. L. 1998. Interaction of tomato spotted wilt tospovirus (TSWV) glycoprotein with a thrips midgut protein, a potential cellular receptor for TSWV. Phytopathology 88:98-104.

6. Beven, L., Le Henaff, M., Fontenelle, C., and Wroblewski, H. 1996. Inhibition of spiralin processing by the lipopeptide antibiotic globomycin. Curr. Microbiol. 33:317-322.

7. Bordier, C. 1981. Phase separation of integral membrane proteins in Triton X-114 solution. J. Biol. Chem. 256:1604-1607.

8. Bradford, M. M. 1976. A rapid and sensitive method for the quantification of microgram quantities of protein utilizing the principal of protein-dye binding. Anal. Biochem. 72:248-254.

9. Calavan, E. C., and Bové, J. M. 1989. Ecology of Spiroplasma citri. Pages 425-485 in: The Mycoplasma, Vol. 5. R. F. Whitcomb and J. G. Tully, eds. Academic Press, New York.

10. Castano, S., Blaudez, D., Desbat, B., Dufourcq, J., and Wroblewski, H. 2002. Secondary structure of spiralin in solution, at the air/water interface, and its interaction with lipid monolayers. Biochim. Biophys. Acta 1562:45-56.

11. Chevalier, C., Saillard, C., and Bové, J. M. 1990. Organization and nucleotide sequences of the Spiroplasma citri genes for ribosomal protein S2, elongation factor Ts, spiralin, phosphofructokinase, pyruvate kinase, and an unidentified protein. J. Bacteriol. 172:2693-2703.

12. Davis, E. R., Jomantiene, R., and Dally, E. L. 2003. Folatte biosynthesis pseudogenes, $\Psi$ folP and $\Psi$ folK, and $O$-sailoglycoprotein endopeptidase gene homolog in the phytoplasma genome. DNA Cell Biol. 22:697-607.

13. Duret, S., Berho, N., Danet, J. L., Garnier, M., and Renaudin, J. 2003. Spiralin is not essential for the helicity, motility, or pathogenicity but is required for efficient transmission of Spiroplasma citri by its leafhopper vector Circulifer haematoceps. Appl. Environ. Microbiol. 69:6225-6234.

14. Fessler, J. H., and Fessler, L. I. 1989. Drosophila extracellular matrix. Annu. Rev. Cell Biol. 5:309-339.

15. Fletcher, J., Wayadande, A., Melcher, U., and Ye, F. 1998. The phytopathogenic mollicute-insect vector interface: A closer look. Phytopathology 88:1351-1358

16. Foissac, X., Danet, J. L., Saillard, C., Gaurivaud, P., Laigret, F., Pare, C., and Bové, J. M. 1997. Mutagenesis by insertion of Tn4001 into the genome of Spiroplasma citri: Characterization of mutants affected in plant pathogenicity and transmission to the plant by the leafhopper vector Circulifer haematoceps. Mol. Plant-Microbe Interact. 10:454-461.

17. Foissac, X., Saillard, C., Gandar, J., Zreik, L., and Bové, J. M. 1996. Spiralin polymorphism in strains of Spiroplasma citri is not due to differences in posttranslational palmitoylation. J. Bacteriol. 178:2934-2940.

18. Fos, A., Bové, J. M., Lallemand, J., Saillard, C., Vignault, J. C., Ali, Y., Brun, P., and Vogel, R. 1986. The leafhopper Neoaliturus haematoceps is a vector of Spiroplasma citri in the Mediterranean area. Ann. Inst. Pasteur-Microbiol. 137:97-107.

19. Grabenhorst, E., Hofer, B., Nimtz, M., Jäger, V., and Conradt, H. S. 1993. Biosynthesis and secretion of human interleukin 2 glycoprotein variants from baculovirus-infected Sf 21 cells. Characterization of polypeptide and posttranslational modifications. Euro. J. Biochem. 215:189-197.

20. Hollister, J., Conradt, H., and Jarvis, D. L. 2003. Evidence for a sialic acid salvaging pathway in lepidopteran insect cells. Glycobiology 13:487495.

21. Homann, H. E., Willenbrink, W., Buchholz, C. J., and Neubert, W. J. 1991. Sendai virus protein-protein interactions studied by a protein blotting protein-overlay technique: Mapping of domains on NP protein required for binding to P protein. J. Virol. 65:1304-1309.
22. Kahane, I., Greenstein, S., and Razin, S. 1977. Carbohydrate content and enzymic activities in the membrane of Spiroplasma citri. J. Gen. Microbiol. 101:173-176.

23. Kaloostian, G. H., Oldfield, G. N., Pierce, H. D., and Calavan, E. C. 1979. Spiroplasma citri and its transmission to citrus and other plants by leafhoppers. Pages 447-450 in: Leafhopper Vectors and Plant Disease Agents. K. Maramorosch and K. F. Harris, eds. Academic Press, New York.

24. Krivan, H. C., Olsonll, L. D., Barile, M. F., Ginsburg, V., and Roberts, D. D. 1989. Adhesion of Mycoplasma pneumoniae to sulfated glycolipids and inhibition by dextran sulfate. J. Biol. Chem. 264:9283-9288.

25. Kwon, M. O., Wayadande, A. C., and Fletcher, J. 1999. Spiroplasma citri movement into the intestines and salivary glands of its leafhopper vector, Circulifer tenellus. Phytopathology 89:1144-1151.

26. Laemmli, U. K. 1970. Cleavage of structural proteins during the assembly of the head of bacteriophage T4. Nature 227:680-685.

27. Layh-Schmitt, G., Podtelejnikov, A., and Mann, M. 2000. Proteins complexed to the P1 adhesin of Mycoplasma pneumoniae. Microbiology 146:741-747.

28. Liu, H. Y. 1981. The transmission, multiplication and electron microscopic examination of Spiroplasma citri in its vector, Circulifer tenellus. $\mathrm{Ph} . \mathrm{D}$. thesis. University of California, Riverside.

29. Liu, H. Y., Gumpf, D. J., Oldfield, G. N., and Calavan, E. C. 1983. The relationship of Spiroplasma citri and Circulifer tenellus. Phytopathology 73:585-590.

30. Lopez, M., Tetaert, D., Juliant, S., Gazon, M., Cerutti, M., Verbert, A., and Delannoy, P. 1999. O-Glycosylation potential of lepidopteran insect cell lines. Biochem. Biophys. Acta 1427:49-61.

31. Loveless, R. W., and Feizi, T. 1989. Sialo-oligosaccharide receptors for Mycoplasma pneumoniae and related oligosaccharides of poly- $N$ acetyllactosamine series are polarized at the cilia and apical-microvillar domains of the ciliated cells in human bronchial epithelium. Infect. Immun. 57:1285-1289.

32. Marchal, I., Jarvis, D. L., and Verbert, A. 2001. Glycoproteins from insect cells: Sialylated or not. Biol. Chem. 382:151-159.

33. Markham, P. G., Townsend, R., Bar-Joseph, M., Daniels, M. J., Plaskitt, A., and Meddins, B. M. 1974. Spiroplasmas are the causal agent of citrus little-leaf disease. Ann. Appl. Biol. 78:49-57.

34. Mouchés, C., Vignault, J. C., Tully, J. G., Whitcomb, R. F., and Bové, J. M. 1979. Characterization of spiroplasmas by one- and two-dimensional protein analysis on polyacrylamide slab gels. Curr. Microbiol. 2:69-74.

35. Oldfield, G. N. 1987. Leafhopper vectors of the citrus stubborn disease spiroplasma. Pages 151-159 in: Proc. 2nd Int. Workshop on Leafhoppers and Planthoppers of Economic Importance. M. R. Wilson and L. R. Nault, eds. CIE, London.

36. Oldfield, G. N., Kaloostian, G. H., Pierce, H. D., Calavan, E. C., Granett, A. L., and Blue, R. L. 1976. Beet leafhopper transmit citrus stubborn disease. Calif. Agric. 30:15.

37. Oldfield, G. N., Kaloostian, G. H., Pierce, H. D., Calavan, E. C., Granett, A. L., Blue, R. L., Rana, G. L., and Gumpf, D. J. 1977. Transmission of Spiroplasma citri from citrus by Scaphytopius nitridus. Phytopathology 67:763-765.

38. Özbek, E., Miller, S. A., Meulia, T., and Hogenhout, S. A. 2003. Infection and replication sites of Spiroplasma kunkelii (class: Mollicutes) in midgut and malpighian tubules of leafhopper Dalbulus maidis. J. Invert. Pathol. 82:167-75.

39. Razin, S., and Jacobs, E. 1992. Mycoplasma adhesion. J. Gen. Microbiol. 138:407-422.

40. Roberts, D. D., Olson, L. D., Barile, M. F., Ginsberg, V., and Krivan, H. C. 1989. Sialic acid-dependent adhesion of Mycoplasma pneumoniae to purified glycoproteins. J. Biol. Chem. 264:9289-9293.

41. Rottem, S. 2002. Invasion of mycoplasmas into and fusion with host cells. Pages 391-401 in: Molecular Biology and Pathogenicity of Mycoplasmas. S. Razin and R. Hermann, eds. Kluwer Academic/Plenum Publishers, New York

42. Rottem, S. 2003. Interaction of mycoplasmas with host cells. Physiol. Rev. 83:417-432.

43. Saglio, P., Laflèche, D., Bonisol, C., and Bové, J. M. 1971. Culture in vitro des mycoplasmes associés au stubborn des agrumes et leur observation au microscope électronique. C. R. Acad. Sci. Paris 272:1387-1390.

44. Saillard, C., and Bové, J. M. 1983. Application of ELISA to spiroplasma detection and classification. Pages 471-478 in: Methods in Mycoplasmology. S. Razin and J. G. Tully, eds. Academic Press, New York.

45. Seddas, P., Boissinot, S., Strub, J. M., Van Dorsselaer, A., Van Rgenenmortel, M. H. V., and Pattus, F. 2004. Rack-1 GAPDH3, and actin: Proteins of Myzus persicae potentially involved in the transcytosis of beet western yellows virus particles in the aphid. Virology 325:399-412.

46. Simoneau, P., and Labarere, J. 1989. Detection of a concanavalin-a binding-protein in the mollicute Spiroplasma citri and purification from the plasma-membrane. Arch. Microbiol. 152:488-491. 
47. Towbin, H., Staehelin, T., and Gordon, J. 1979. Electrophoretic transfer of proteins from polyacrylamide gels to nitrocellulose sheets: Procedure and some application. Biochemistry 76:4350-4354.

48. Tully, J. G., Whitcomb, R. F., Clark, H. F., and Williamson, D. L. 1977. Pathogenic mycoplasma: Cultivation and vertebrate pathogenicity of a new spiroplasma. Science 195:892-894.

49. Van den Heuvel, J. F. J. M., Verbeek, M., and Peters, D. 1993. The relationship between aphid-transmissibility of potato leafroll virus and surface epitopes of the viral capsid. Phytopathology 83:1125-1129.

50. Van den Heuvel, J. F. J. M., Verbeek, M., and van der Wilk, F. 1994. Endosymbiotic bacteria associated with circulative transmission of potato leafroll virus by Myzus persicae. J. Gen. Virol. 75:2559-2565.

51. Vignault, J. C., Bové, J. M., Saillard, C., Vogel, R., Farro, A., Venegas, L., Stemmer, W., Aoki, S., McCoy, R. E., Al-beldawi, A. S., Larue, M., Tuzco, O., Ozan, M., Nhami, A., Abassi, M., Bonfils, J., Moutous, G., Fos, A., Poutiers, F., and Viennot-Bourgin, G. 1980. Mise en culture de spiroplasmes à partir de matériel végétal et d'insectes provenant de pays circum méditerranéens et du Proche Orient. C.R. Acad. Sci. Paris 290:775-780.

52. Wayadande, A. C., and Fletcher, J. 1995. Transmission of Spiroplasma citri lines and their ability to cross gut and salivary gland barriers within the leafhopper vector Circulifer tenellus. Phytopathology 85: 1256-1259.

53. Wieslander, A., Boyer, M. J., and Wroblewski, H. 1992. Membrane protein structure. Pages 93-112 in: Mycoplasmas-Molecular Biology and Pathogenesis. J. Maniloff, R. N. McElhaney, L. R. Finch, and J. B. Baseman, eds. American Society for Microbiology, Washington, DC.

54. Wright, C. S. 1984. Structural comparison of the two distinct sugar binding sites in wheat germ agglutinin isolectin II. J. Mol. Biol. 178:91104.

55. Wroblewski, H., Johansson, K. E., and Hjérten, S. 1977. Purification and characterization of spiralin, the main protein of the Spiroplasma citri membrane. Biochim. Biophys. Acta 465:275-289.

56. Yu, J., Wayadande, A. C., and Fletcher, J. 2000. Spiroplasma citri surface protein P89 implicated in adhesion to cells of the vector Circulifer tenellus. Phytopathology 90:716-722.

57. Zhang, Q., Young, T. F., and Ross, R. F. 1994. Microtiter plate adherence assay and receptor analogs for Mycoplasma hyopneumoniae. Infect. Immun. 62:1616-1622.

58. Zhang, Q., Young, T. F., and Ross, R. F. 1994. Glycolipid receptors for attachment of Mycoplasma hyopneumoniae to porcine respiratory ciliated cells. Infect. Immun. 62:4367-4373. 